\title{
Tourism Impacts and Support for Tourism Development in Ha Long Bay, Vietnam: An Examination of Residents' Perceptions
}

\author{
Pham Hong Long ${ }^{1}$ \\ ${ }^{1}$ Faculty of Tourism Studies, College of Social Sciences and Humanities, Vietnam National University, Hanoi, \\ Vietnam \& Graduate School of Tourism, Rikkyo University, Saitama, Japan \\ Correspondence: Pham Hong Long, PhD Candidate, Graduate School of Tourism, Rikkyo University, 1-2-26 \\ Kitano, Niiza-shi, Saitama 352-8558, Japan. Tel: 81-90-6044-1076. E-mail: \\ longph@vnu.edu.vn/phamhonglong@gmail.com
}

Received: March 9, 2012 Accepted: April 9, $2012 \quad$ Published: July 1, 2012

doi:10.5539/ass.v8n8p28 URL: http://dx.doi.org/10.5539/ass.v8n8p28

\begin{abstract}
The impacts of tourism have been given much attention by scholars attempting to examine the perceptions as well as attitudes of the local residents toward tourism. Such studies have been carried out thoroughly in the context of the developed countries. However, very little research has been carried out in developing countries. This study attempts to make a little contribution to the sustainable development of tourism by examining the residents' profile, perceptions and attitudes towards tourism impacts and tourism development in Ha Long Bay, the Vietnam's first World Heritage Site (recognized in 1994). Data were collected by means of a questionnaire study. Based on 417 respondents surveyed, the findings show that the majority of respondents were young, Kinh rather than other ethnic group, they were married and were living in Ha Long Bay for over 20 years. On the whole, respondents viewed tourism positively and would support tourism development. They were generally in favor of tourism that contributes economically and socio-culturally to Ha Long Bay. They were, however, slightly ambivalent to environmental impacts of tourism. Implications, policy recommendations and limitations of study are presented in the conclusion.
\end{abstract}

Keywords: Vietnam, Ha Long Bay, residents' perceptions, residents' attitudes, tourism impacts, support for tourism development

\section{Introduction}

Tourism development has been identified as an effective way to revitalize the economy of a destination, whether rural or urban (Chen \& Chen, 2010). However, tourism industry relies heavily upon the local residents' goodwill, participation and support (Andriotis, 2005; Yoon, Gursoy, \& Chen, 2001). Tourism, therefore, should be developed according to the local residents' need and desires. An understanding local residents' perceptions of tourism impacts and their attitudes toward tourism development is fundamental for the success and sustainability of any type of tourism development (Allen, Long, Perdue, \& Kieselbach, 1988; Gursoy, Chi, \& Dyer, 2009; Kuvan \& Akan, 2005; Lankford \& Howard, 1994; Yoon et al., 2001). Though a wealth of research has examined residents' perceptions as well as their attitudes toward tourism impacts and tourism development, especially in developed countries, they are still a relatively new concern for tourism researchers and scholars of a developing country such as Vietnam. In Vietnam, up to the present, not so many studies of this kind have been attempted, except for several studies by P. H. Long (2011), and P. H. Long and Kayat (2011)

This research paper represents preliminary findings from a study of residents' perceptions of tourism impacts and their support for tourism development in Ha Long Bay, Quang Ninh, Viet Nam. There are four main objectives of this research paper:

(i) to identify the socio-demographic characteristics of the local residents,

(ii) to examine residents' perceptions of tourism impacts, overall evaluation of tourism impacts,

(iii) to explore residents' support for tourism development, and

(iv) to make recommendations and suggestions for tourism policy, planning of the study area. 
This kind of study is very important since the constant question faced by many destinations is how to plan for optimal tourism development, while at the same time minimize the impacts of its development on the resident population. One approach is to monitor residents' opinions of perceived impacts as a means of incorporating community local people's reaction into tourism planning and development (Jackson, 2008). Hence, a systematic analysis of tourism impacts and support for tourism development perceived by Ha Long Bay residents can help local authorities, planners, community decision-makers, tour-operators, and tourism promoters to identify real concerns and issues in order to implement appropriate and effective policies and actions in the area, thus optimizing the benefits and minimizing the problems associated with tourism.

This study proposes an inclusive resident-centric approach to tourism policy making rather than a top-down approach.

This paper is divided into six sections. Following the introduction, the second section reviews the documents related to this study. The third section describes the study area. The fourth reviews the methodology of study. The fifth section presents the findings and discussion of the study and the final section provides the conclusions and the policy recommendations.

\section{Literature Review}

Tourism has been referred to as a "goose that not only lays a golden egg, but also fouls its own nest" (Julio, 2001). Like many other industries, it is often used as a national or regional development tool (Jackson, 2008; Liu \& Var, 1986). However, tourism development without proper planning and integration with local values and environment can bring forth socio-cultural, environmental and economic damage to host population (Lee, $\mathrm{Li}, \&$ Kim, 2007; Tatoglu, Erdal, Ozgur, \& Azakli, 2002) .

In general, tourism development within a host community often impacts the community both in negative and positive ways. These impacts are often classified into economic, socio-cultural and environmental tourism impacts (Allen et al., 1988; Chen \& Chen, 2010; Jackson, 2008; Kuvan \& Akan, 2005; Liu, Sheldon, \& Var, 1987; Liu \& Var, 1986; P. H. Long, 2011; P. H. Long \& Kayat, 2011; P. T. Long, Perdue, \& Allen, 1990; Nepal, 2008; Pérez \& Nadal, 2005). Economic tourism impacts have an impact on the economic base of residents. These comprise positive elements such as employment opportunities, economic growth, higher standard of living, infrastructure development, as well as negative elements such as inflation, economic instability, seasonal temporary employment, tax burdens. Socio-cultural tourism impacts affect the social and cultural life of residents, including positive elements such as quality of life improvement, intercultural communication and understanding, resurgence traditional practices, pride in community, and negative elements such as crime rate and tension increasing, authenticity loss, residents' attitude worsening. Environmental tourism impacts embrace impacts of tourism on the environment, usually comprising positive elements such as preservation of historical buildings and monuments, improved area's appearance, and negative elements such as crowding, the pollution of air, soil, water, noise, litter, traffic and parking congestion, the depletion of natural resources, land construction.

In fact, empirical research investigating and identifying tourism impacts perceived by residents is vast. Two features of residents' perceived impact can be concluded: first, the perceived impact consists of multi-dimensions, such as economic, socio-cultural and environmental; and second, both positive and negative elements of each dimension should be taken in account. In general, there is divergence of perceptions about the impacts of tourism by residents of host communities. Residents with a positive perceived tourism impact are more likely to support additional tourism development and have higher willingness to participate in an exchange with visitors. On the other hand, residents are likely to oppose tourism development when they perceive more costs than benefits brought about by the tourism development (Chen \& Chen, 2010; Jackson, 2008; Lankford, 1994; Liu \& Var, 1986). The trade-off between benefits and costs is often explained through social exchange theory, which suggests that individuals will engage in and support activities if the perceived benefits are greater than the perceived costs. Consequently, if residents believe that the benefits of tourism exceed its potential costs, they will be supportive of tourism development (John, 1990; Jurowski \& Gursoy, 2004; Yoon et al., 2001).

Earlier researchers and scholars have suggested that despite the availability of research on residents' perceptions as well as attitudes toward tourism and its impacts, it is necessary to conduct research on this topic in other geographical locations, in different settings, and over a period of time in order to not only reinforce earlier findings but also identify and explore other factors that may influence the host residents' to those issues (Andriotis, 2004, 2005; Cavus \& Tanrisevdi, 2003; Haralambopoulos \& Pizam, 1996; Kuvan \& Akan, 2005; Sheldon \& Var, 1984; Smith \& Krannich, 1998; Yoon et al., 2001). 
According to Cevat (2001), every study of tourism impacts is unique because it is related to its own characteristics, which makes it difficult to derive its worldwide validity. It implies the need for the study of tourism impacts on residents in each specific region.

This current study examined the impact of tourism development as a trade-off between local residents' perceived benefits (i.e. positive impacts) and costs (i.e. negative impacts). Both positive and negative impacts include in three dimensions - economic, socio-cultural and, environmental - of support for tourism development.

\section{Area of Study}

The site selected in this study is Ha Long Bay in Quang Ninh province, which is located in the North-East of Vietnam (See for Figure 1). It is an area of superlative natural beauty. It is also a treasure house of unusual and often unique geomorphic features, ecosystems and bio-diversity. There are many sites of historical significance and archaeological remains in and around the Bay and it is strongly represented in myths and legends of the Vietnamese people (Galla, 2002). Ha Long Bay has been recognized twice by UNESCO as a World Natural Heritage for its universal value of landscape and geology, geomorphology, in 1994 and 2000 respectively. In addition, it has been recently voted as one of the new seven natural wonders of the world in 2011.

Ha Long Bay is an important site both economically and culturally for Vietnam, and has played a significant role in the development for the country as an international tourism destination. It is one of Vietnam's premier tourism destinations (Hien, 2011). According to the figures from the Cultural Office of Ha Long City, during 2002, 1.7 million people visited the Bay. By 2011, there were more than 4 million annual visitors, $50 \%$ being foreigners (Ha Long, 2012). The number of visitor has been increasing continuously for years.

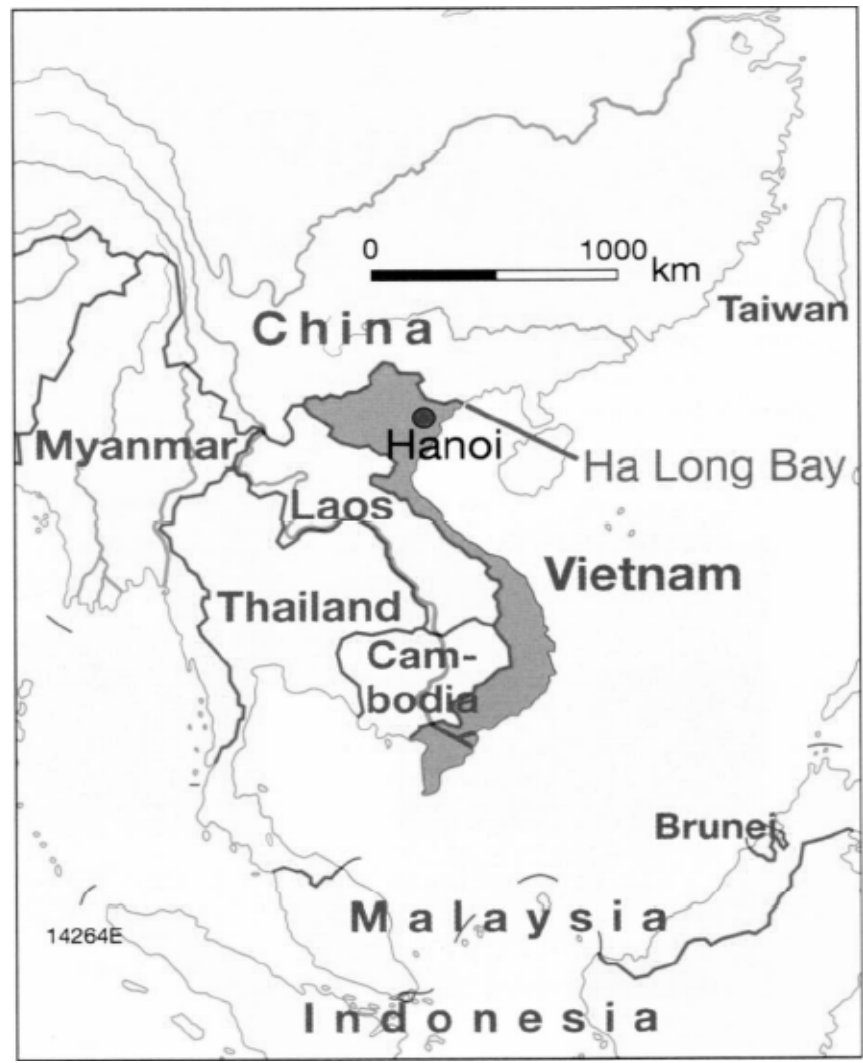

Figure 1. Location of Ha Long Bay in Vietnam

Source: Mark (2009)

In spite of the tremendous expansion of the Ha Long tourism industry and the knowledge that the attitudes and perceptions of local residents are vital for the success of tourism, little is known about the local residents' perceptions of tourism. Although, there appears to be substantial research on tourism activities in Ha Long Bay, no published research has, so far, dealt with the residents' perception of the impacts of tourism and their attitudes toward and support for tourism development in Ha Long Bay. Hence, there is a need for a study that will build on the existing, albeit limited body of knowledge concerning these issues 


\section{Methodology}

This study was exploratory and used descriptive statistics to measure residents' perception of tourism impacts and their support for tourism development. The methodology followed the multiphase approach proposed by Mason and Cheyne (2000). This approach comprised a review of literature, questionnaire development, pre-test and field survey.This method was chosen because it has resulted in better response rates than other methods in previous studies (Nunkoo \& Ramkissoon, 2009).

The questionnaire using in this study was compiled using previously tested questions used by Akis, Peristianis, and Warner (1996); Andereck and Vogt (2000); Andriotis (2004); Andriotis and Vaughan (2003); Belisle and Hoy (1980); Chen and Chen (2010); Haralambopoulos and Pizam (1996); Huttasin (2008); Johnson, Snepenger, and Akis (1994); King, Pizam, and Milman (1993); Kuvan and Akan (2005); Lee et al. (2007); Liu and Var (1986); McCool and Martin (1994); Nunkoo and Ramkissoon (2009); Perdue, Long, and Allen (1990); Puczkó and Rátz (2000); Rudež and Vodeb (2010); Schofield (2011); Tatoglu et al. (2002); Tovar and Lockwood (2008); Yoon et al. (2001). Their works on residents' perceptions of tourism impacts, tourism development served as models for this study. However, since questions in those studies were developed in settings different to the present study site, the statements were adapted to Ha Long Bay, taking into consideration its culture, geography, environment and the dynamics of tourism development. In addition, most of the items on "support for tourism development" were originally developed for the purpose of the study. The questionnaire consisted of 53 items, covered in 4 parts: Part 1-3:44 statement items meant to measure residents' perceptions of tourism impacts, their overall assessment of tourism impacts, and support for tourism development were included in these parts, followed by a five point Likert Scale for the respondents' opinions $(1=$ strongly disagree, $2=$ disagree, $3=$ undecided/neutral, $4=$ agree, $5=$ strongly agree); Part 4 : This part comprised of 9 questionnaires pertaining to the socio-demographic characteristics of residents but no names were collected, thus retaining the privacy of the respondents. The last question requested the respondents to provide any additional comments that they wished to make regarding tourism development in Ha Long Bay. The questionnaire was designed to examine an extensive study of the impacts of tourism in Ha Long Bay. In this research paper, only local residents' perceptions of tourism impacts will be descriptively displayed and discussed.

Subsequent to the development of the questionnaire, an appropriate pilot test was conducted with a sample of 30 residents in Ha Long Bay. The results of the pilot test provided valuable information and the instrument was amended accordingly. The questionnaire is therefore being contextual rather than conceptual.

The study was carried out over six-week period between September and October 2011. Of the 600 distributed questionnaires among the local people, living and working in the vicinity of Ha Long Bay, 480 were collected, and 63 of them were then rejected because they were considered as incomplete and were therefore eliminated from the analysis.

Data obtained were entered and analyzed using Statistic Package for the Social Science (SPSS) version 19.0. Descriptive statistic was used to investigate residents' perception of the economic, socio-cultural and environmental impacts, overall tourism impacts and support for tourism development in Ha Long Bay.

\section{Findings and Discussion}

\subsection{Profile of Respondents}

Table 1. Descriptive results of demographic variable

\begin{tabular}{lrr}
\hline Demographic variables & Frequency $^{\mathrm{a}}$ & Percentage \\
\hline Age (in years) & & \\
$18-25$ & 129 & 30.9 \\
$26-35$ & 137 & 32.9 \\
$36-55$ & 106 & 25.4 \\
$56-60$ & 35 & 8.4 \\
Over 60 & 10 & 2.4 \\
Gender & & \\
Male & 207 & 49.6 \\
Female & 210 & 50.4
\end{tabular}


Ethnic group

Kinh

Others

Place of birth

Ha Long Bay

Others

Marital status

Single

Married

Divorced

Widowed

Education

No schooling

Primary school

Secondary school

High school

College

University

Others

Monthly household income ${ }^{\mathbf{b}}$

Below VND 500,000

VND 500,000-1,000,000 3.8

VND 1,000,001-2,000,000 12.5

VND 2,000,001-3,000,000 18.9

VND 3,0 00,001-4,000,000 27.6

Above VND 4,000,000

Job status

Tourism-related

Not tourism-related

Retired

Unemployed/disabled

Length of residency

Less than 1 year

1-5 years

6-10 years

11-15 years

16-20 years

$\mathbf{a} . n=417 ;{ }^{\mathbf{b}} .1 \mathrm{USD}=21,000 \mathrm{VND}$

As shown in Table 1, the majority of respondents $(63.8 \%)$ were young, less than the age of 35 , with the largest age category being 26-35 age group (32.9\%). Male and female respondents were closely equal (49.6\% and $50.4 \%$ ). Kinh respondents exceedingly outnumbered other respondents in the current study by $94.5 \%$ to $5.5 \%$. More than half of respondents were married (54.4\%), while 42.2\% were still single. In terms of education level, 
there was a concentration at the college and university level $(32.9 \%$ and $32.1 \%$, respectively). The monthly household income of the majority of respondents (63.3\%) was above 3,000,000 Vietnamese Dong (VND). With regard to employment status, $43.9 \%$ of the respondents indicated that they were currently involved in the tourism industry, while $48.7 \%$ were not tourism-related. The most frequently reported period of residence was over 20 years. This period was reported by $34.8 \%$ of respondents.

\subsection{Economic Impacts}

Table 2. Residents' perceptions of the economic impacts of tourism

\begin{tabular}{|c|c|c|c|}
\hline Rank $^{\mathrm{a}}$ & Questions on survey instrument & Mean $^{\mathrm{b}}$ & $\begin{array}{l}\text { Percentage } \\
\text { agree }^{c}\end{array}$ \\
\hline 1 & Tourism has improved employment opportunities in Ha Long Bay. & 4.21 & 87.1 \\
\hline 2 & $\begin{array}{l}\text { Tourism is one of the most important industries supporting the local } \\
\text { economy. }\end{array}$ & 4.15 & 85.4 \\
\hline 3 & Tourism creates new business opportunities for local residents. & 4.10 & 84.4 \\
\hline 4 & $\begin{array}{l}\text { The prices of many goods and services in Ha Long Bay have increased } \\
\text { because of tourism. }\end{array}$ & 4.00 & 78.7 \\
\hline 5 & Tourism has attracted more investment to Ha Long Bay. & 3.94 & 75.1 \\
\hline 6 & Real estate prices in the community have increased because of tourism. & 3.89 & 76.0 \\
\hline 7 & Our standard of living has increased considerably because of tourism. & 3.62 & 58.5 \\
\hline 8 & $\begin{array}{l}\text { The quality of public services in Ha Long Bay is now better due to } \\
\text { tourism investment. }\end{array}$ & 3.53 & 55.5 \\
\hline 9 & Seasonal tourism has created high-risk, under-or unemployment issues. & 3.24 & 41.5 \\
\hline 10 & $\begin{array}{l}\text { Tourism income generated in the area goes out to outside organizations } \\
\text { and individuals. }\end{array}$ & 3.08 & 32.9 \\
\hline 11 & Income from tourism benefits only a few people in Ha Long Bay. & 2.87 & 30.9 \\
\hline 12 & $\begin{array}{l}\text { Tourism development in Ha Long Bay interferes with the residents' daily } \\
\text { economic activities. }\end{array}$ & 2.23 & 8.4 \\
\hline
\end{tabular}

${ }^{\mathbf{a}}$.Questions are ranked by mean values; ${ }^{\mathbf{b}}$.scale ranges from $1=$ strongly disagree to $5=$ strongly agree; ${ }^{\mathbf{c}}$. percentage agreeing are those answering 4,5 on the 5-point scale

Concerning the economic impacts of tourism, the results as indicated in Table 2 show that there is a strong agreement about the economic benefits of tourism to the economy of Ha Long Bay. These include employment opportunities (87.1\%) and an important industry supporting the local economy (85.4\%). $75.1 \%$ respondents recognized that tourism has attracted more investment to Ha Long Bay. It was also felt that due to tourism invesment, the quality of public services is now better (55.5\%).

While $84.4 \%$ of respondents remarked the fact that tourism creates new business opportunities for local residents, only $58.5 \%$ held that tourism has increased their standard of living. Notably, respondents exclaimed that the tourism also increased the cost of living, with $76.0 \%$ indicating that tourism is responsible for increases in real estate prices, while $78.7 \%$ indicated that tourism has resulted in an increase in the prices of many goods and services in Ha Long Bay. Nearly half of respondents thought that seasonal tourism has brought the high-risk, under-or-unemployment issues.

It also appears as though the benefits of tourism are widely dispersed in Ha Long Bay as $32.9 \%$ of respondents indicated that tourism income generated goes out to outside organizations and individuals, while only $30.9 \%$ believed that income from tourism accrues to a minority of residents. Only a handful of respondents (8.4\%) felt that tourism interferes with their daily economic activities. This is not surprising as tourism is considered to play a vital role in the local economy. 


\subsection{Social-Cultural Impacts}

Table 3. Residents' perceptions of the socio-cultural impacts of tourism

\begin{tabular}{|c|c|c|c|}
\hline $\operatorname{Rank}^{\mathrm{a}}$ & Questions on survey instrument & Mean $^{\mathrm{b}}$ & $\begin{array}{l}\text { Percentage } \\
\text { agree }^{\mathrm{c}}\end{array}$ \\
\hline 1 & $\begin{array}{l}\text { Tourism has increased residents' pride in the local culture in Ha Long } \\
\text { Bay. }\end{array}$ & 4.21 & 86.8 \\
\hline 2 & $\begin{array}{l}\text { Tourism has resulted in greater cultural exchange between tourists and } \\
\text { residents. }\end{array}$ & 3.99 & 77.7 \\
\hline 3 & $\begin{array}{l}\text { Tourism has improved the quality of products and services of tourism } \\
\text { infrastructure such as roads, transportation systems, restaurants, shops, } \\
\text { and guest-houses in the area. }\end{array}$ & 3.98 & 78.4 \\
\hline 4 & $\begin{array}{l}\text { Tourism encourages a wide variety of cultural activities like crafts, art, } \\
\text { and music in Ha Long Bay. }\end{array}$ & 3.87 & 72.9 \\
\hline 5 & $\begin{array}{l}\text { Owing to tourism development, local people now have more recreational } \\
\text { opportunities. }\end{array}$ & 3.78 & 69.3 \\
\hline 6 & Tourism has improved residents' overall quality of life. & 3.76 & 68.6 \\
\hline 7 & $\begin{array}{l}\text { Tourism has helped to preserve the cultural identity of the local } \\
\text { population }\end{array}$ & 3.63 & 62.1 \\
\hline 8 & $\begin{array}{l}\text { Tourism contributes social problems such as crime, drug use, } \\
\text { prostitution, excessive drinking, alcoholism, gambling, robbery, } \\
\text { smuggling, and so on in Ha Long Bay. }\end{array}$ & 3.35 & 50.6 \\
\hline 9 & Local residents have suffered by living in a tourism destination area. & 2.76 & 27.3 \\
\hline 10 & $\begin{array}{l}\text { It is becoming increasingly difficult to find a quiet place for recreation } \\
\text { around here because of tourists. }\end{array}$ & 2.61 & 21.1 \\
\hline 11 & $\begin{array}{l}\text { Tourism encourages residents to imitate the behavior of the tourists and } \\
\text { relinquish cultural traditions. }\end{array}$ & 2.58 & 18.9 \\
\hline 12 & $\begin{array}{l}\text { Tourism has limited the use of the recreational facilities such as } \\
\text { entertainment and recreation centers, sport complex and beachesfor the } \\
\text { local people. }\end{array}$ & 2.46 & 13.9 \\
\hline 13 & Tourism damages to the local culture. & 2.35 & 13.4 \\
\hline 14 & $\begin{array}{l}\text { The increase in tourist numbers has led to alienation between tourists and } \\
\text { residents. }\end{array}$ & 2.31 & 10.1 \\
\hline
\end{tabular}

$\bar{a}$.Questions are ranked by mean values; ${ }^{\mathbf{b}}$.scale ranges from $1=$ strongly disagree to $5=$ strongly agree; ${ }^{\mathbf{c}}$. percentage agreeing are those answering 4,5 on the 5-point scale

As shown in Table 3, opinions on tourism's sociocultural impacts emphasize the positive benefits of tourism which residents can enjoy. Specifically, these include items such as residents' pride of the local culture (86.8\%), the improved quality of products and services of tourism infrastructure $(78.4 \%)$, cultural exchange between tourists and residents $(77.7 \%)$, and encouragement of a variety of cultural activities $(72.9 \%)$. The next most agreed statements are that local people have more recreational opportunities $(69.3 \%)$, and their quality of life has become better thanks to tourism (68.6\%).

It is interesting that, although $62.1 \%$ of respondents indicated that tourism has helped to preserve the cultural identity of the local population, $50.6 \%$ blamed tourism for contributing social problems such as crime, drug use, prostitution, excessive drinking, alcoholism, gambling, robbery, smuggling and so on.

The other negative impacts of tourism were not significant in the perceptions of the respondents in Ha Long Bay who perceived only slightly that they have suffered by living in a tourism destination area (27.3\%), that tourism as the cause of difficulty in finding a quiet place for recreation (21.1\%), and that tourism encourages residents to imitate the behaviour of the tourists and to relinquish cultural traditions (18.9\%). Additionally, a mere 13.9\% believed that tourism has limited the local residents' use of the recreational facilities, while only $13.4 \%$ linked tourism to the local culture's damage. Respondents also did not perceive that the increase in tourist numbers has led to alienation between tourists and residents. This might be indicative of the fact that tourism provides economic benefits to Ha Long Bay and residents in Ha Long Bay get used to see tourists.Overall, except for social problem item, the rest of data does not reveal any major concerns towards the perceived negative social impacts of tourism in Ha Long Bay. 


\subsection{Environmental Impacts}

Despite the high levels of agreement on both the positive economic and socio-cultural impacts of tourism, it appears as though Ha Long Bay residents seemed slightly ambivalent about the positive environmental impacts of tourism (Table 4). On one hand, respondents agreed that due to tourism, the appearance of Ha Long Bay became better (68.3\%), and tourism provides an incentive for the restoration of historic buildings $(64.7 \%)$. On the other hand, respondents blamed tourism for its environmental costs, such as traffic congestion, solid waste, air, water, noise and soil pollution (58.0\%). Additionally, a little more than half of respondents $(53.7 \%)$ felt that tourism makes natural landscape and agricultural lands less available.

Table 4. Residents' perceptions of the environmental impacts of tourism

\begin{tabular}{clcc}
\hline Rank $^{\mathrm{a}}$ & Questions on survey instrument & Mean & $\begin{array}{c}\text { Percentage } \\
\text { agree }^{\mathrm{c}}\end{array}$ \\
\hline 1 & Tourism has improved the area's appearance (visual and aesthetic). & 3.75 & 68.3 \\
2 & $\quad$ Tourism provides an incentive for the restoration of historic buildings. & 3.64 & 64.7 \\
3 & $\begin{array}{l}\text { Tourism has caused significant traffic congestion, solid waste and air, } \\
\text { water, noise, and soil pollution. }\end{array}$ & 3.52 & 58.0 \\
4 & $\begin{array}{l}\text { Because of the tourism, there are now fewer natural landscapes and } \\
\text { agricultural lands in the area. }\end{array}$ & 3.43 & 53.7 \\
5 & $\begin{array}{l}\text { Tourism has contributed to the preservation of the natural environment } \\
\text { and the protection of the world heritage site of Ha Long Bay. }\end{array}$ & 3.37 & 50.1 \\
6 & $\begin{array}{l}\text { Tourism has improved the ecological environment of Ha Long Bay in } \\
\text { many ways. }\end{array}$ & 3.30 & 45.8 \\
7 & $\begin{array}{l}\text { Tourism facilities built in and around Ha Long Bay are not harmony with } \\
\text { the natural environment and traditional architecture. }\end{array}$ & 3.24 & 40.8 \\
8 & $\begin{array}{l}\text { The construction of hotels, guest-houses in the area has destroyed the } \\
\text { natural beauty of the coastline. }\end{array}$ & 3.21 & 42.9 \\
9 & $\begin{array}{l}\text { Tourism has negative impacts on the natural resources (including } \\
\text { collection of plants, animals, rocks, or artifacts by or for tourists). }\end{array}$ & 3.12 & 37.9 \\
\hline
\end{tabular}

a . Questions are ranked by mean values; ${ }^{b}$. scale ranges from $1=$ strongly disagree to $5=$ strongly agree; ${ }^{c}$. percentage agreeing are those answering 4, 5 on the 5-point scale

Only about half the respondents agreed that tourism has contributed to the preservation of the natural environment and the protection of the world heritage site of Ha Long Bay (50.1\%), improved the ecological environment of Ha Long Bay (45.8). On the negative side, not surprisingly, only a small number of the respondents believed that tourism facilities built in and around Ha Long Bay are not in harmony with the natural environment and traditional architecture (40.8\%), the construction of hotels, guest-houses in the area has destroyed the natural beauty of the coastline. Respondents were also not willing to admit that tourism has negative impacts on the natural resources (37.9\%).

\subsection{Overall Evaluation of Tourism Impacts}

In terms of overall evaluation of tourism impacts or in other words, tourism trade-offs, $58.0 \%$ of respondents indicated that the benefits of tourism exceed its cost to Ha Long Bay. Only a small number of respondents (13.7\%) believed that tourism development in Ha Long Bay produces more negative impacts than positive impacts.

Table 5. Residents' overall evaluation of tourism impacts

\begin{tabular}{rlrr}
\hline Rank $^{\mathrm{a}}$ & Questions on survey instrument & Mean $^{\mathrm{b}}$ & $\begin{array}{c}\text { Percentage } \\
\text { agree }^{\mathrm{c}}\end{array}$ \\
\hline 1 & $\begin{array}{l}\text { Overall, I believe that the benefits of tourism exceed its costs to Ha Long } \\
\text { Bay. }\end{array}$ & 3.63 & 58.0 \\
2 & $\begin{array}{l}\text { I think tourism development in Ha Long Bay produces more negative } \\
\text { impacts than positive impacts. }\end{array}$ & 2.45 & 13.7 \\
\hline
\end{tabular}

a. Questions are ranked by mean values; ${ }^{\mathrm{b}}$. scale ranges from $1=$ strongly disagree to $5=$ strongly agree; ${ }^{\mathrm{c}}$. percentage agreeing are those answering 4,5 on the 5-point scale 


\subsection{Support for Tourism Development}

Table 6. Residents' support for tourism development

\begin{tabular}{rlrr}
\hline Rank $^{\mathrm{a}}$ & Questions on survey instrument & Mean & $\begin{array}{c}\text { Percentage } \\
\text { agree }^{\mathrm{c}}\end{array}$ \\
\hline 1 & $\begin{array}{l}\text { The government should control tourism development in Ha Long Bay in } \\
\text { order to maximize the benefits and minimize the cost of development. }\end{array}$ & 4.36 & 91.6 \\
2 & $\begin{array}{l}\text { The community should support tourism development in Ha Long Bay. } \\
3\end{array}$ & 4.31 & 92.6 \\
4 & $\begin{array}{l}\text { I would like to see more tourists in Ha Long Bay. } \\
\text { I amilling to be involved in the development of Ha Long Bay for }\end{array}$ & 4.29 & 88.2 \\
5 & $\begin{array}{l}\text { The government should increase its effort to provide infrastructure to } \\
\text { support tourism development in Ha Long Bay. }\end{array}$ & 4.28 & 86.8 \\
6 & $\begin{array}{l}\text { I am willing to be a part of tourism planning for Ha Long Bay in the } \\
\text { future. }\end{array}$ & 4.23 & 83.5 \\
7 & $\quad$ I support tourism as having a vital economic role in Ha Long Bay. & 4.22 & 90.4
\end{tabular}

a . Questions are ranked by mean values; ${ }^{b}$. scale ranges from $1=$ strongly disagree to $5=$ strongly agree; ${ }^{c}$. percentage agreeing are those answering 4,5 on the 5-point scale

As shown in Table 6, all the items obtained agreement by more than $80 \%$ of the respondent. Given these positive attitudes, it is therefore no wonder that the majority of respondents indicated that they would be in favor of tourism as having a vital economic industry in their city (90.4\%), and they would like to welcome more tourists in Ha Long Bay (88.2\%), as well as they are willing to participate in the sustainable development of tourism $(86.8 \%)$, and be a part of tourism planning for Ha Long Bay in the future $(83.5 \%)$. These findings indicate that respondents value the benefits that tourism brings, but would like to participate in decision-making process in regards to tourism development and growth in Ha Long Bay.Respondentsalso felt that local government should control tourism impacts (91.6\%) and provide more infrastructure to support tourism development (92.6\%). $92.6 \%$ of respondents also concerned about the role of community in supporting tourism development in $\mathrm{Ha}$ Long Bay. This could indicate the community in Ha Long Bay is still not really active in tourism and therefore it should increase its more effort to support tourism development.

Overall, the positive support for tourism development is not surprising and can be explained by social exchange theory which assumes that potential beneficial outcomes will create positive attitudes towards tourism(John, 1990; Jurowski \& Gursoy, 2004; Yoon et al., 2001). Given the fact that Ha Long Bay is one of the most famous well-established and well-known tourist sites in Vietnam and many residents are largely dependent on tourism, the theory is therefore somehow supported.

\section{Conclusions and Implications}

This study attempts to make a little contribution to those studies that have targeted a specific community within a destination and seek to the sustainable development of tourism by examining the residents' profile, perceptions and attitudes towards tourism impacts and tourism development in Ha Long Bay, Vietnam.

The findings of this research show up that the majority of respondents were young, Kinh rather than other ethnic group, they were married and were living in Ha Long Bay for over 20 years. The high dependence of Ha Long Bay residents on tourism is reflected by the fact that nearly half of its respondents were employed in tourism industry.

Having to depend so much on tourism, it is not surprising that respondents in Ha Long put high hopes for success and tended to have positive attitudes toward tourism. Despite the perception of some negative impacts of tourism, respondents perceived the overall impacts as beneficial. Respondents in the study area associated tourism with an important industry supporting the local econony, employment opportunities, investment-business opportunities to Ha Long Bay, variety of cultural activities, cultural exchange, recreational activities and restoration of historic buildings. However, tourism was blamed for inflated real estate prices and the increases in the cost of many goods and services; causing traffic congestion, solid waste, air, water, noise and soil pollution; and making natural landscapes and agricultural lands less available. Respondents also indicated that they believe tourism can help to improve residents' living standard and quality of life, foster residents' pride of their local culture, bring good quality of products and services to tourism transportation, and make the 
appearance of Ha Long Bay better. Consequently, they are content to live with negative consequences since they were outweighted by the positive benefits. Respondents were almost reluctant to attribute socio-cultural and environmental costs to tourism, however.

The study also suggests that respondents highly supported tourism development, but were concerned most about the roles of government and local community in controlling and supporting tourism. Based on the results of the study, the following recommendations are made:

First, local tourism makers and planners should seek residents' perceptions and attitudes in advance of starting development actions rather than to put top-down plans and programs. This will enable them to assess local sentiments, which should be incorporate into tourism policy planning.

Second, those responsible for tourism planning must find ways to mitigate and minimize perceived negative impacts of tourism, especially environmental impacts. Ignoring negative consequences of tourism might make it difficult to promote tourism and may also lead to resentment among resident, which will not make them want to welcome tourists (McDowall \& Choi, 2010).

Third, local government, destination development and management personnel should include local residents in the decision-making process so that they can voice their opinions. This must be addressed as respondents are willing to be involved in tourism development and be a part of tourism planning in Ha Long Bay.

It is important to consider the limitations of study. Due to the reason that there are distinctive shortages in studies on tourism impacts, residents' perceptions of tourism impacts, tourism development in Vietnam in general and in Ha Long Bay in particular, the literature review was biased as the existing literature was drawn mainly from the studies conducted in industrialized countries, such as the United State, Australia, and several countries in Europe. Additionally, this study was conduct in Ha Long Bay at one of the peak tourist seasons. Consequently, this might have missed some representatives of the population, especially those who work in tourism industry. Thus, the findings might not be generalized to the whole population due to biases that might have existed. To avoid the perceptional bias on the residents of tourism impacts, future studies should focus on longitudinal studies in both peak and off-peak and seasons. Such a kind of longitudinal research could be conducted to help recognize the changes in perception which may happen as a result of tourism development on the host community.

\section{Acknowledgements}

The author would like to thank Associate Professor Kalsom Kayat, Tourism and Hospitality Programme, UUM College of Art and Sciences, Universiti Utara Malaysia, 06010 UUM Sintok, Kedah, Malaysia, for her comments to strengthen this research.

\section{References}

Akis, S., Peristianis, N., \& Warner, J. (1996). Residents' attitudes to tourism development: the case of Cyprus. Tourism Management, 17(7), 481-494. http://dx.doi.org/10.1016/s0261-5177(96)00066-0

Allen, L. R., Long, P. T., Perdue, R. R., \& Kieselbach, S. (1988). The Impact Of Tourism Development On Residents' Perceptions Of Community Life. Journal of Travel Research, 27(1), 16-21. http://dx.doi.org/10.1177/004728758802700104

Andereck, K. L., \& Vogt, C. A. (2000). The Relationship between Residents' Attitudes toward Tourism and Tourism Development Options. Journal of Travel Research, 39(1), 27-36. http://dx.doi.org/10.1177/004728750003900104

Andriotis, K. (2004). The perceived impact of tourism development by Cretan residents. Tourism and Hospitality: Planning \& Development, 1(2), 123-144. http://dx.doi.org/10.1080/1479053042000251061

Andriotis, K. (2005). Community Groups' Perceptions of and Preferences for Tourism Development: Evidence from Crete. Journal of Hospitality \& Tourism Research, 29(1), 67-90. http://dx.doi.org/10.1177/1096348004268196

Andriotis, K., \& Vaughan, R. D. (2003). Urban Residents' Attitudes toward Tourism Development: The Case of Crete. Journal of Travel Research, 42(2), 172-185. http://dx.doi.org/10.1177/0047287503257488

Belisle, F. J., \& Hoy, D. R. (1980). The perceived impact of tourism by residents a case study in Santa Marta, Colombia. Annals of Tourism Research, 7(1), 83-101. http://dx.doi.org/10.1016/s0160-7383(80)80008-9

Cavus, S., \& Tanrisevdi, A. (2003). Residents Attitudes toward Tourism Development: A Case Study in Kusadasi, Turkey. Tourism Analysis, 7(3-4), 259-269. http://dx.doi.org/10.3727/108354203108750102 
Cevat, T. (2001). Challenges of sustainable tourism development in the developing world: the case of Turkey. Tourism Management, 22(3), 289-303. http://dx.doi.org/10.1016/s0261-5177(00)00060-1

Chen, C.-F., \& Chen, P. C. (2010). Resident Attitudes toward Heritage Tourism Development. Tourism Geographies, 12(4), 525-545. http://dx.doi.org/10.1080/14616688.2010.516398

Galla, A. (2002). Culture and Heritage in Development: Ha Long Ecomuseum, A Case Study from Vietnam. Humanities Research, 9(1), 63-76.

Gursoy, D., Chi, C. G., \& Dyer, P. (2009). An Examination of Locals' Attitudes. Annals of Tourism Research, 36(4), 723-726. http://dx.doi.org/10.1016/j.annals.2009.06.003

Ha Long, C. (2012). In 2011: More than 4 million tourists visited Ha Long. Retrieved 10/3/2012, from http://hotels-halong.com.vn/193/nam-2011-hon-4-trieu-luot-khach-du-lich-den-ha-long/

Haralambopoulos, N., \& Pizam, A. (1996). Perceived impacts of tourism: The case of samos. Annals of Tourism Research, 23(3), 503-526. http://dx.doi.org/10.1016/0160-7383(95)00075-5

Hien, B. T. T. (2011). Ha Long Bay World Heritage Area - Governance Analysis. Governing Marine Protected Areas: Getting the Balance Right (Vol. 2, pp. 136-146). Technical Report to Marine and Coastal Ecosystems Branch, UNEP, Nairobi.

Huttasin, N. (2008). Perceived Social Impacts of Tourism by Residents in the OTOP Tourism Village, Thailand. Asia Pacific Journal of Tourism Research, 13(2), 175-191. http://dx.doi.org/10.1080/10941660802048498

Jackson, L. A. (2008). Residents' perceptions of the impacts of special event tourism. Journal of Place Management and Development, 1(3), 240-255. http://dx.doi.org/10.1108/17538330810911244

John, A. (1990). Residents' perceptions research on the social impacts of tourism. Annals of Tourism Research, 17(4), 610-616. http://dx.doi.org/10.1016/0160-7383(90)90032-m

Johnson, J. D., Snepenger, D. J., \& Akis, S. (1994). Residents' perceptions of tourism development. Annals of Tourism Research, 21(3), 629-642. http://dx.doi.org/10.1016/0160-7383(94)90124-4

Julio, A. (2001). The host should get lost: Paradigms in the Tourism Theory. Annals of Tourism Research, 28(3), 738-761. http://dx.doi.org/10.1016/s0160-7383(00)00075-x

Jurowski, C., \& Gursoy, D. (2004). Distance Effects on Residents' Attitudes toward Tourism. Annals of Tourism Research, 31(2), 296-312. http://dx.doi.org/10.1016/j.annals.2003.12.005

King, B., Pizam, A., \& Milman, A. (1993). Social impacts of tourism: Host perceptions. Annals of Tourism Research, 20(4), 650-665. http://dx.doi.org/10.1016/0160-7383(93)90089-1

Kuvan, Y., \& Akan, P. (2005). Residents' attitudes toward general and forest-related impacts of tourism: the case of Belek, Antalya. Tourism Management, 26(5), 691-706. http://dx.doi.org/10.1016/j.tourman.2004.02.019

Lankford, S. V. (1994). Attitudes and Perceptions Toward Tourism and Rural Regional Development. Journal of Travel Research, 32(3), 35-43. http://dx.doi.org/10.1177/004728759403200306

Lankford, S. V., \& Howard, D. R. (1994). Developing a tourism impact attitude scale. Annals of Tourism Research, 21(1), 121-139. http://dx.doi.org/10.1016/0160-7383(94)90008-6

Lee, T. J., Li, J., \& Kim, H.-K. (2007). Community Residents' Perceptions and Attitudes Towards Heritage Tourism in a Historic City. Tourism and Hospitality Planning \& Development, 4(2), 91-109. http://dx.doi.org/10.1080/14790530701554124

Liu, J. C., Sheldon, P. J., \& Var, T. (1987). Resident perception of the environmental impacts of tourism. Annals of Tourism Research, 14(1), 17-37. http://dx.doi.org/10.1016/0160-7383(87)90045-4

Liu, J. C., \& Var, T. (1986). Resident Attitudes toward Tourism Impacts in Hawaii. Annals of Tourism Research, 13(2), 193-214. http://dx.doi.org/10.1016/0160-7383(86)90037-X

Long, P. H. (2011). Perceptions of Tourism Impact and Tourism Development among Residents of Cuc Phuong National Park, Ninh Binh, Vietnam. Journal of Ritsumeikan Social Sciences and Humanities, 3, 75-92.

Long, P. H., \& Kayat, K. (2011). Residents' perceptions of tourism impact and their support for tourism development: the case study of Cuc Phuong National Park, Ninh Binh province, Vietnam. European Journal of Tourism Research, 4(2), 123-146. 
Long, P. T., Perdue, R. R., \& Allen, L. (1990). Rural Resident Tourism Perceptions And Attitudes By Community Level Of Tourism. Journal of Travel Research, 28(3), 3-9. http://dx.doi.org/10.1177/004728759002800301

Mark, H. (2009). Karst Landscape in the Bay of Ha Long, Vietnam. Geographische Rundschau International Edition, 5(1).

Mason, P., \& Cheyne, J. (2000). Residents' attitudes to proposed tourism development. Annals of Tourism Research, 27(2), 391-411. http://dx.doi.org/10.1016/s0160-7383(99)00084-5

McCool, S. F., \& Martin, S. R. (1994). Community Attachment and Attitudes Toward Tourism Development. Journal of Travel Research, 32(3), 29-34. http://dx.doi.org/10.1177/004728759403200305

McDowall, S., \& Choi, Y. (2010). A Comparative Analysis of Thailand Residents' Perception of Tourism's Impacts. Journal of Quality Assurance in Hospitality \& Tourism, 11(1), 36-55. http://dx.doi.org/10.1080/15280080903520576

Nepal, S. K. (2008). Residents' Attitudes to Tourism in Central British Columbia, Canada. Tourism Geographies, 10(1), 42-65. http://dx.doi.org/10.1080/14616680701825123

Nunkoo, R., \& Ramkissoon, H. (2009). Small island urban tourism: a residents' perspective. Current Issues in Tourism, 13(1), 37-60. http://dx.doi.org/10.1080/13683500802499414

Perdue, R. R., Long, P. T., \& Allen, L. (1990). Resident support for tourism development. Annals of Tourism Research, 17(4), 586-599. http://dx.doi.org/10.1016/0160-7383(90)90029-q

Pérez, E. A., \& Nadal, J. R. (2005). Host community perceptions a cluster analysis. Annals of Tourism Research, 32(4), 925-941. http://dx.doi.org/10.1016/j.annals.2004.11.004

Puczkó, L., \& Rátz, T. (2000). Tourist and Resident Perceptions of the Physical Impacts of Tourism at Lake Balaton, Hungary: Issues for Sustainable Tourism Management. Journal of Sustainable Tourism, 8(6), 458-478. http://dx.doi.org/10.1080/09669580008667380

Rudež, H. N., \& Vodeb, K. (2010). Perceived tourism impacts in municipalities with different tourism concentration. Tourism - An International Journal, 50(2), 161-172.

Schofield, P. (2011). City resident attitudes to proposed tourism development and its impacts on the community. International Journal of Tourism Research, 13(3), 218-233. http://dx.doi.org/10.1002/jtr.814

Sheldon, P. J., \& Var, T. (1984). Resident attitudes to tourism in North Wales. Tourism Management, 5(1), 40-47. http://dx.doi.org/10.1016/0261-5177(84)90006-2

Smith, M. D., \& Krannich, R. S. (1998). Tourism dependence and resident attitudes. Annals of Tourism Research, 25(4), 783-802. http://dx.doi.org/10.1016/s0160-7383(98)00040-1

Tatoglu, E., Erdal, F., Ozgur, H., \& Azakli, S. (2002). Resident Attitudes Toward Tourism Impacts. International Journal of Hospitality \& Tourism Administration, 3(3), 79-100. http://dx.doi.org/10.1300/J149v03n03_07

Tovar, C., \& Lockwood, M. (2008). Social impacts of tourism: an Australian regional case study. International Journal of Tourism Research, 10(4), 365-378. http://dx.doi.org/10.1002/jtr.667

Yoon, Y., Gursoy, D., \& Chen, J. S. (2001). Validating a tourism development theory with structural equation modeling. Tourism Management, 22(4), 363-372. http://dx.doi.org/10.1016/s0261-5177(00)00062-5 